\title{
METHODS OF TERMINOLOGICAL COMPOSITION EXTENSION IN LANGUAGES FOR SPECIAL PURPOSES \\ IN THE GERMAN CHRISITIAN THEOLOGICAL TERMINOLOGY
}

Veresh M. T.

\section{INTRODUCTION}

Linguistics has different methods and ways of expanding vocabulary in a language, including morphological, syntactic and semantic approaches, as well as borrowing. The same methods are applied to languages for special purposes and related terminology.

With regard to borrowing, the peculiarity of the linguistic situation of the Germans during the period of active borrowing of foreignlanguage lexical units is largely due to the establishment and spread of Christianity in Europe, a religion that, in its linguistic tradition, relied primarily on Latin and Greek. "Religious interferences are related to the influence of religion on language. The writing and the main layer of borrowed vocabulary in each language were subordinate to the respective religion and associated sacred language, that is, the Holy Scripture and worship services, for some historical period. Sometimes the adoption of one or another religion was of great progressive importance, because along with religion, one or another nation borrowed writing that was conducive to the development of education and, indeed, of the entire national culture" ${ }^{1}$. This fact led to the emergence of a special culture of bilingualism, which consisted in the fact that, on the one hand, there was a language of religion and literary writing (in the German-speaking Latin environment), and on the other, a vernacular that was used in everyday life and partly in writing.

1 Д'яков А. С. Основи термінотворення: Семантичні та соціолінгвістичні аспекти / Д’яков А. С. , Кияк Т. Р., Куделько З. Б. - К. : вид. дім “КМ Academia”, 2000 - С. 36. 


\section{Borrowing in the German Christian Theological Terminology}

Along with morphological, syntactic and semantic ways of word formation, terminology expands through borrowing.

V.N. Yartseva defines borrowing as an element of a foreign language (word, morpheme, syntactic construction, etc.), transferred from one language to another due to language contacts, as well as the actual process of transition of elements of one language into another" ${ }^{2}$ In the "Ukrainian language" encyclopaedia, the definition of the linguistic term "borrowing" is "a sound, morpheme, a word or its separate meaning, phraseology, syntactic construction, transferred from one language to another, as well as the process of subsequent transfer." ${ }^{3}$ Both definitions emphasize the importance of moving elements from one language into another. It is more often we borrow lexical units, rather than sounds and phraseologisms. A.A. Reformatskyj believes that borrowed terms are those that "do not mix with ordinary words: they are separate, unambiguous, and stand outside the expression $<\ldots>$. The choice of the source language of these terms is predetermined by real historical practice so that you can show the connection of peoples and nations and the nature of their cultural interaction"4. Borrowings are moved into the language with the concept or subject they designate, depicting a cultural change, scientific and technical development ${ }^{5}$.

H.-R. Fluck extends and clarifies the definition of the term "borrowing", indicating that borrowing denotes a term taken from a foreign language and translated into the language of the recipient with its adaptation to the morphological and phonological system ${ }^{6}$.

There are many reasons, why one should know the reasons and chances for being borrowed. According to M. Haspelmath and U. Tadmor

2 Языкознание. Большой энциклопедический словар / [под ред. В. Н. Ярцевой]. [2-е изд.]. - М. : Большая Российская энциклопедия, 1998. - С. 158.

${ }^{3}$ Українська мова : енциклопедія / [Русанівський В. М, Тараненко О. О., М. П. Зяблюк та ін.]. - [2-ге вид., випр. і доп.]. - К. : Українська енциклопедія ім. М. П. Бажана, 2004. C. 194-195.

4 Реформатский А. А. Термин как член лексической системы языка / А. А. Реформатский // Проблемы структурной лингвистики. - М., 1968. - С. 120.

${ }^{5}$ Stedje A. Deutsche Sprache gestern und heute / A. Stedje. - München, 1989. - S. 25.

${ }^{6}$ Fluck, H.-R. Fachsprachen: Enführung und Bibliographie / Hans-Rüdiger Fluck. [5. überarb. und erw. Aufl.]. - Tübingen : Basel : Francke, 1996. - S. 54. 
they are: "In assessing genealogical relatedness between languages, it is important to separate inherited material from borrowed material. Loanwords point to historical contact between two languages (the presence of people with at least some knowledge of both languages at some stage), but not to genealogical relatedness (i.e. descent from, a common ancestral language). $\langle\ldots>$. The likelihood of lexical borrowing depends on the type of contact situation. $\langle\ldots>$. Borrowing patterns may be influenced by nonsocial, strictly linguistic factors",

In particular, the reasons for linguistic borrowing can be as follows:

- the need for naming (a new thing, a new concept);

- the need for clarification, the implementation of an appropriate concept,

- the need to differentiate meaningfully close, but still different concepts,

- the need for specialization of concepts in various fields and various motives;

- euphemistic substitutions;

- the tendency to replace word combinations and descriptive references with one-word naming;

- consolidation in the language of borrowing, which can be combined into a lexical series based on their general meaning and the repetition of any general structural element;

- the presence of established systems of terms in the borrowed language that serve a particular thematic area, professional environment ${ }^{8}$.

Borrowings are distinguished by several criteria, for instance, whether the way of borrowing is direct or indirect. Direct borrowing is peculiar to the language at the primary stage of formation of terminological systems when there are several borrowings from different languages at the same

${ }^{7}$ Haspelmath M. Loanwords in the Word's Languages : A Comparative Handbook / M. Haspelmath, U. Tadmor. - Walter de Gruyter, 2009. - P. 1.

8 Крысин Л. П. Языковое заимствование как проблема диахронической социолингвистики / Л. П. Крысин // Диахроническая социолингвистика. - М., 1993. C. 146. 
time to indicate the same concept ${ }^{9}$. This type of borrowing comes directly from the so called "donor language". "The language from which a loanword has been borrowed is called the donor language, and the language into which it has been borrowed is the recipient language" ${ }^{\text {. }}$. As examples would be following terms: die Kathedrale < lat. cathedralis (cathedral), der Episkopat < lat. episcopatus (bishop), das Kyrieeleison < gr. kyrios eleein (God, have mercy). Indirect borrowing occurs through a third language ${ }^{11}$. For example, der Synod <ru. sinod < gr. synodos (synod), das Schisma < lat. schisma < gr. schisma, die Theologie < lat. theologia < gr. Theologia (theology).

Noteworthy is the borrowing of "die Kirche" from the Greek word "kyriake" - "the house of the Lord" - one of the few that has been taken over by the Goths into the German vocabulary. However, the internal meaning of the term is determine by the Greek borrowing "ekklesia" (Latin ecclésia). "Ekklesia" denoted the assembly of citizens and people in classical Greek. In the Greek translation of the Old Testament (Septuagint), the word "ekklesia" is used to translate the Hebrew word "qahál" (assembly of the people of God, community). With this meaning, the word enters to the New Testament and already names all the faithful Christians, those newly chosen by God of the Jews and Gentiles, gathered in anticipation of the coming in glory of the crucified and risen Jesus Christ ${ }^{12}$.

In addition, by the nature of the borrowed material, we distinguish direct borrowing in the sense of "originals" and loan translations (or calques). "They are an important type of structural borrowing. A calque (or loan translation) is a complex lexical unit (either a single word or a fixed phrasal expression) that was created by an item-by-item translation of

${ }^{9}$ Даниленко В. П. Русская терминология: Опыт лингвистического описания / В. П. Даниленко. - М. : Наука, - 1977. - С. 74.

${ }^{10}$ Haspelmath M. Lexical borrowing: Concepts and issues : [Електронний ресурс]. Режим доступу : https://www.academia.edu/3453003/Lexical_borrowing_Concepts_and_ issues 2009_

$\overline{11}$ Д'яков А. С. Основи термінотворення: Семантичні та соціолінгвістичні аспекти / Д'яков А. С. , Кияк Т. Р., Куделько 3. Б. - К. : вид. дім “КМ Academia”, 2000 $218 \mathrm{c}$.

${ }^{12}$ Lindquist A. Studien über Wortbildung und Wortwahl im Althochdeutschen mit besonderer Rüchsicht auf die nomina actionis / A. Lindquist // Beiträge zur Geschichte und Sprache der deutschen Literatur. - 1936. - S. 2. 
the source unit"13. D.S. Lotte applies the term "original borrowing" instead of "direct"14, since the term "direct borrowing" may refer to a borrowing path - "direct" meaning without an intermediary language. Therefore, in our work, we use the term "original borrowing".

Original borrowing is a word transferred into the recipient language in the same form it exists in the donor language ${ }^{15}$. The word borrowed with this method remains unchanged and is not affected by the morphological and phonetic system of the recipient language. For instance, die Sukzession < lat. successio, (succession) der Salvator < lat. salvator, (Saviour), das Sakrarium < lat. sacrarium (the Sacrarium).

Along with this, D.S. Lotte identifies "transformative borrowing" by which he means a word or phrase transformed at the time of translation by omitting or adding an element, or replacing a compound word with phrases $^{16}$. For example, neue Theologie < fr. Nouvelle Theologie (new theology), Fest der Kreuzerhöhung < lat. Exaltatio crucis (The Exaltation of the Holy Cross)

Calquing (loan translation) is the literal translation of word elements from the donor language into the recipient language ${ }^{17}$. This method is implemented at the beginning of language science formulation when the language has both its native word and borrowing at the same time ${ }^{18}$. For example, die Kardinaltugend < lat. virtutes cardinales (cardinal virtues), heiliges Officium < lat. Sanctum Officium (Congregation for the Doctrine of the Faith).

The materials for the study of the genetic composition of the borrowings include 2230 terminological units of the "Theologisches

${ }^{13}$ Haspelmath M. Lexical borrowing: Concepts and issues : [Електронний ресурс]. Режим доступу : https://www.academia.edu/3453003/Lexical_borrowing_Concepts_and_ issues_2009_

${ }_{14}$ Лотте Д. С. Вопросы заимствования и упорядочения иноязычных терминов и терминоэлементов / Д. С. Лотте. - М. : Наука, 1982. - С. 10.

15 Лотте Д. С. Вопросы заимствования и упорядочения иноязычных терминов и терминоэлементов / Д. С. Лотте. - М. : Наука, 1982. - С. 10-14.

16 Лотте Д. С. Вопросы заимствования и упорядочения иноязычных терминов и терминоэлементов / Д. С. Лотте. - М. : Наука, 1982. - С. 10-14.

17 Д'яков А. С. Основи термінотворення: Семантичні та соціолінгвістичні аспекти / Д'яков А. С., Кияк Т. Р., Куделько 3. Б. - К. : вид. дім “КМ Academia”, 2000 C. 110 .

${ }^{18}$ Даниленко В. П. О терминологическом словообразовании / В. П. Даниленко // Вопросы языкознания. - М. , 1973. - № 4. - С. 76. 
Fach- und Fremdwörterbuch" Dictionary by F. Hauck and G. Schwinge ${ }^{19}$. During the research process, the following have been identified: in the vocabulary of German theological terminological units of Latin origin 1508 terms - comprise the largest number of borrowings, which is $67.62 \%$ of the total number of the processed borrowings.

First of all, these are borrowings related to:

- systematic theology (die Konfession - religious denomination, die Inkarnation - Incarnation, die Dogmatik - Dogmatic theology, die Immaculata - Immaculate Mary, die Deifikation - deification;

- system and structure of the church (die Kurie - Curia, Habemus papam - We have a pope, die Konklave - papal conclave, die Kongregation - congregation, der Generalvikar - vicar general);

- Church Canon Law (die Jurisdiktion - jurisdiction, jus canonicum - canon law, die Infallibilität - Papal infallibility, ex cathedra cathedra, bishop's throne, die Exkommunikation - Excommunication, die Rota Romana - Roman Rota, the highest appellate tribunal);

- Liturgical and ceremonial areas (der Kantor - cantor, die Kapelle - chapel, die Adoration - adoration).

Such a high frequency of Latinisms in the studied terminological system is due not only to the fact that Latin has long remained dominant in the field of theology, but also because it maintains the status of a theological language today.

The second largest group contains loanwords from the Greek language, 585 terms, which is $26.24 \%$ of the total number of loans processed. Among the Greek borrowings are the following thematic groups:

- terms of church and ceremonial dress that are primarily used in the Eastern tradition (die Mitra - mitre, Panagia - Panaghia, sakkos - sakkos, omophorion - omophorion, phelonion - phelonion);

- terms of worship (Kondakion - kontakion, Troparion - troparion);

- systematic theology (philokalia - philokalia, die Theologie theology, die Theophanie - Theophany, die Eucharistie - Eucharist,

${ }^{19}$ Hauck F. Theologisches Fach- und Fremdwörterbuch / F. Hauck, G. Schwinge [10., Aufl.]. - Göttingen : Vandenhoeck \& Ruprecht, 2005. - 240 S. 
theotokos - Mother of Jesus), Holy Scripture (die Exegese - exegesis, der Exodus - Exodus, das Deuteronomium - Deuteronomy);

- terms related to church government (der Exarch - exarch).

Moreover, the dictionary includes terminological units borrowed from the ancient/biblical Hebrew language - 92 units (4.13\% of the total number of the processed loanwords). As a rule, these are concepts connected with Judaism and the Holy Scripture (der Pharisäer - Pharisees, der Sadduzäer - Sadducees, der Rabbi - Rabbi, der Sabbat - Shabbat, das Passah -Pesach, Halleluja - Hallelujah, Praise ye, Yah, der Cherubim cherub, das Hosianna - hosanna, Immanuel - God (El) with us).

Furthermore, there are loanwords from modern European languages: Italian -14 units, which is $0.63 \%$ of the total number of the processed borrowings (Bambino Jesu - Baby Jesus, die Madonna - Madonna, Santo Uffizio - Congregation for the Doctrine of the Faith, Scala santa - Scala Santa, Holy Stairs); French - 13 units, which forms $0,58 \%$ of the total amount of the analysed loan terminology (der Abbé - Abbé, das Skapulier - scapular, die Soutane - cassock or soutane). A small number of loanwords are Aramaic lexical units - ten - which is $0.45 \%$ of the total number of the examined borrowings (Golgotha - Golgotha, der Mammon - Mammon). Records of borrowing with the designation russ. is present in 5 cases - 0,23\% of the processed loanwords (archijerej archiereus, Starez - starets, Strannik - wanderer). One borrowing (0.04\% of the total number of the processed loanwords) was recorded from Old Slavic (Glagoliza - Glagolitic script), Persian (Paradies - Paradise) and Syriac (Peschitta - simple, the translation of the Bible in the Syriac of the IV th century). Quantitative indicators of borrowing terms of the Christian theological German language term system are presented in Table 1.

$67.62 \%$ of Latin borrowings in German Christian theological terminology are because the theological terminology of the German language developed under the intense influence of the classical languages, especially Latin. For a long time Latin remained the only language in the church and liturgical usage of the European peoples, including by the time of the Second Vatican Council (1962-1965). 
The borrowing of theological terms from different languages

\begin{tabular}{|l|c|c|}
\hline Languages & $\begin{array}{c}\text { The absolute } \\
\text { number of units } \\
\text { (units) }\end{array}$ & $\begin{array}{c}\text { The relative } \\
\text { amount of units } \\
(\%)\end{array}$ \\
\hline Latin & 1508 & $67,62 \%$ \\
\hline Greek & 585 & $26,24 \%$ \\
\hline ancient/biblical Hebrew & 92 & $4,13 \%$ \\
\hline Italian & 14 & $0,63 \%$ \\
\hline French & 13 & $0,58 \%$ \\
\hline Arameic & 10 & $0,45 \%$ \\
\hline Russian & 5 & $0,23 \%$ \\
\hline Old Slavic & 1 & $0,04 \%$ \\
\hline Persian & 1 & $0,04 \%$ \\
\hline Syriac & 1 & $0,04 \%$ \\
\hline Total & 2230 & $100 \%$ \\
\hline
\end{tabular}

In the German language of theology, there are cases where "specific terms that have replaced the terminological units of Greek and Latin origin remain as doublets" ${ }^{20}$ : das Glaubensbekenntnis - Credo (profession of faith), der Lobgesang - das Benediktus (hymn of praise), die Anbetung die Adoration (adoration), der Vaterunser - Paternoster (Lord's Prayer), die Erscheinung Gottes - Theophanie (The Transfiguration of Jesus).

Considering our topic, it is necessary to distinguish between internationalism and borrowing. Internationalism differs from simple borrowing: any element can only be addressed as "international" if it exists in at least three unrelated languages. If this condition is missing, then there is no reason to call a before-mentioned borrowing "internationalism", for it is only an ordinary borrowing at the national level $^{21}$. T. Sekunda believes that "international terms can be regarded as such, if they are being used with the same meaning in most European

${ }^{20}$ Arntz R. Einführung in die Terminologiearbeit / R. Arntz, H. Picht, F. Mayer. [5., verb. Aufl.]. - Hildesheim, Zürich, New York : Olms, 2004. - S.120.

${ }^{21}$ Кияк Т. Р. Запозичення та інтернаціоналізми у фахових мовах : [Електронний pecypc] / Т. Р. Кияк // Вісник Житомирського державного університету імені Івана Франка. - 2006. - № 27. - С. 32-34. - Режим доступу : http://eprints.zu.edu.ua/ 1068/1/06ktpifm.pdf. 
languages, especially highly cultural languages" 22 . Under international vocabulary, O. Kokojlo assumes words or terms that are used in the same form and with the same meanings in many languages and by peoples of Europe, Asia and other continents ${ }^{23}$. However, an important criterion for determining international and national is the presence of the word in at least three unrelated languages ${ }^{24,25}$. Internationalism is a borrowed lexical unit that exists in at least three languages with the same meaning, while retaining the overall material form and taking into account the geographical, grammatical and phonetic features of the recipient language. Frequently, the etymological basis of internationalism is the classical languages, that are Greek and Latin ${ }^{26}$.

International words are part of the vocabulary of different languages; however, etymologically they derive from the common token, both the sound structure and the semantics of which are close to each other or identical. Generally, internationalism is a lexical unit that constitutes phono-morphological variants of words or morphemes, which extend to unrelated languages and have identical or similar semantics and graphics in these languages ${ }^{27,28,29}$. Thereby, the term der Kardinal < lat. cardinalis (cardinal) has an international character, as in Ukrainian cardinal sounds (кардинал - cardinal), in Hungarian kardinális, in French cardinal. More examples are presented in Table 2.

22 Секунда Т. Принципи складання української технічної термінології / Т. Секунда // Вісник Ін-ту укр. наук. мови. - 1930. - Вип. 2. - С. 15.

${ }^{23}$ Кокойло О. В. Інтернаціональна лексика в російській та іспанській мовах / О. В. Кокойло, Н. М. Корбозерова // Мовознавство. - 1987. - № 2. - С. 27.

24 Володина М. Н. Национальное и интернациональное в процессе терминологической номинации / М. Н. Володина. - М. : Изд-во Моск. ун-та. - 1993. C. 33 .

25 Бельчиков Ю. А. Интернациональная терминология в русском языке / Ю. А. Бельчиков. - М. : Учпедгиз, 1959. - С. 3.

26 Жербило Т. В. Термины и понятия лингвистики : Общее языкознание. Социолингвистика : Словарь-справочник / Т. В. Жербило. - Назрань : Пилигрим, 2011. - С. 90.

27 Акуленко В. В. Вопросы интернационализации словарного состава языка / В. В. Акуленко. - Харьков: изд-во Харьк. ун-та, 1972. - 244 с.

${ }^{28}$ Белецкий А. А. Об интернационализмах / А. А. Белецкий // Науч. зап. Киев. ун-та. 1955. - Т. 14. - Вип. 2. - С. 59-80.

29 Бельчиков Ю. А. Интернациональная терминология в русском языке / Ю. А. Бельчиков. - М. : Учпедгиз, 1959. - 78 с. 
Table 2

Internationalisms

\begin{tabular}{|l|c|c|c|c|}
\hline $\begin{array}{l}\text { Latin/ Greek/ } \\
\text { Hebrew }\end{array}$ & German & French & Hungarian & Ukrainian \\
\hline altaria & der Altar & autel & oltár & олтар \\
\hline $\begin{array}{l}\text { amen/ amēn/ } \\
\text { àmēn }\end{array}$ & amen & amen & ámen & амінь \\
\hline $\begin{array}{l}\text { catechismus/ } \\
\text { katēchēin }\end{array}$ & $\begin{array}{c}\text { der } \\
\text { Katechismus }\end{array}$ & catechisme & katechizmus & катехизм \\
\hline cathedralis & die Kathedrale & cathedrale & katedrális & коад'ютор \\
\hline coadiutor & der Koadjutor & coadjuteur & koadjutor & колия \\
\hline $\begin{array}{l}\text { pentateuchus/ } \\
\text { pentateuchos }\end{array}$ & der Pentateuch & Pentateuque & Pentateuchus & П'ятикнижжя \\
\hline
\end{tabular}

In the Christian theological terminology of the German language internationalisms is a phenomenon, given the fact that most of the borrowed terms underlying internationalisms of this terminological system are of Latin, Greek, and Hebrew origin. Latin, for instance, has served as the primary language in theological usage for centuries and gave force to the creation of terms in specific national languages.

\section{Phraseoterms in the German theological terminology}

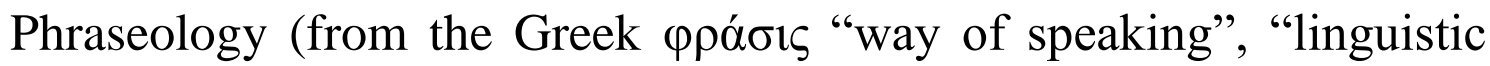
appeal" and $\lambda$ ó $\gamma o \varsigma$ science) was previously defined as an 'oratorical expression'. Ch. Palm describes phraseology as "the science or doctrine of the permanent word combinations of the language, which can take over the functions and meanings of individual words (tokens) in the system and in the sentence. That is why phraseology is the means of expanding (enriching) the vocabulary composition, for nomination" 30 .

Currently, phraseology is regarded as a unit of linguistics, which deals with phraseologisms. W. Fleischer considers phraseologisms to be syntactic phrases that are different from free phrases and contain at least one autosemantic element ${ }^{31}$.

${ }^{30}$ Palm Ch. Phraseologie. Eine Einführung / Ch. Palm. - Tübingen, 1995. - S. 1.

${ }^{31}$ Fleischer W. Phraseologie der deutschen Gegenwartssprache / W. Fleischer. Tübingen: Max Niemeyer Verlag, 1997. - S. 29-37, 62-65. 
Ch. Bally defines phraseology a complex expression which encompasses "a group of words where every graphic unit of this group loses some of its meaning or even retains no meaning at all; the combination of these elements acts as an integral content unit" ${ }^{\prime 32}$.

As to their form, phraseological units do not differ from free phrases. The difference is in the general semantics, since idioms present a peculiar two-level meaning; namely, they are carriers of proper verbal meaning and phraseological meaning. To put it differently, the verbal meaning is associative, has hidden meaning, while the phraseological is the actual meaning. In some instances, based on the meaning of the individual elements of the expression, we can determine the meaning of the whole phraseology. "The fact that phraseologies have an integral meaning that does not coincide with the meaning of the individual elements does not mean that there is no link between the total verbal meaning on the one hand and the phraseological meaning on the other. On the contrary, if we compare both meanings, it is often possible to establish a relation between them",33.

Considering the semantic features of phraseologies in the language, we should note that the phraseological units reveal certain features in the course of the phraseological meaning formation; the phraseological unit is subject to double semantic influence. On the one hand, "it is the bearer of certain interpreted pre-verbal meanings, based on which the meaning of the phraseological unit was formed, i.e. the systematic content. On the other hand, the use of in the discourse of linguistic units with actualized elements of systemic meaning generates new content which is verbalized by secondary nomination signs" ${ }^{\text {34 }}$. K. D. Pilz believes that phraseologies consist of at least two words, forming a verbal group/syntagms, which, although written separately, but are elements of one semantic unit. This group of words is fixed by its elements and acts as an equal unit in the

${ }^{32}$ Bally Ch. Traite de stylistique francaise / Ch. Bally. - [2. Aufl.]. - 2. Bd. Heidelberg, 1921. - S. 65-66.

${ }^{33}$ Burger H. Handbuch der Phraseologie / H. Burger, A. Buhofer, A. Sialm. - Berlin, 1982. - S. 3.

34 Альфиренко Н.Ф. Фразеология в свете современных лингвистических парадигм : Монография / Н. Ф. Альфиренко. - М. : Элипс, 2008. - С. 27. 
vocabulary composition; it is a token, which belongs to the language and is not recreated in the spoken language but used from its vocabulary ${ }^{35}$. Semantically, the peculiarity of the usage of phraseology also depends on "how an idiom differs from its non-phraseological equivalent; this implies the way this phraseologism modifies the possible and typical expressions into which it is embedded"36.

Phraseoterms are usually terminological expressions, the meaning of which is primarily defined only within the professional linguistic system. Phraseoterms can perform various pragmatic functions in the text; it depends on certain factors, including communication. In our case, theology is the language for special purposes. Phraseologisms in languages for special purposes are quite extensive and require a particularly careful approach to their study. Therefore, H. Burger, I. M. Vignans'ka, M. Dume, R. Eckert, O.A. Zhilenko, O. I. Molotkov, K. D. Pilz, N.V. Podols'ka, O. V. Superans'ka V. Fleischer and others investigate this topic.

With regard to phraseological terms, we should highlight that distinguishing common phraseological units and professional ones is considered a difficult task. The phraseological terms of Christian theological terminology form a particular group of expressions that function "as a separate word-term" $"$. Precisely, their semantics are clearly outlined, that is, normalized, and that it happens within the professional language. The integrity of professional phraseological units, depending on the professional context, is expressed differently. R. Eckert believes that multi-component terms and established professional expressions belong to phraseology and are regarded as phraseological units ${ }^{38}$. Another group of linguists do not perceive multi-component expressions as elements of phraseology. Thus, A. Molotkov denies the transfer of the scheme of phraseology formation through the reinterpretation of basic phrases into

\footnotetext{
${ }^{35}$ Pilz K. D. Phraseologie: Redensartenforschung / K. D. Pilz. - Stuttgart, 1981. - S. 20.

36 Kühn P. Pragmatische und lexikographische Beschreibung phraseologischer Einheiten: Phraseologismen und Routineformeln // Studien zur neuhochdeutschen Lexikographie IV. - [hrgb. Wiegand, H.E.]. - Hildesheim, Zürich, New York, 1984. - S. 195.

${ }^{37}$ Burger. H. Phraseologie. Eine Einführung am Beispiele des Deutschen / H. Burger. Berlin : Erich Schmidt Verlag, 2003. - S. 50.

${ }^{38}$ Eckert R. Die Phraseologie der russischen Sprache / R. Eckert, K. Günther. - Leipzig, Berlin, 1992. - S. 58.
} 
the formation of terminological phrases" ${ }^{39}$. V. Thalia shares the same opinion, regarding as phraseoterms only those terminological phrases that, unlike ordinary phrases, indeed, contain terminological character as a special character and have undergone a process of semantic reinterpretation ${ }^{40}$. Fleischer concludes that the main difference between terminological expressions, on the one hand, and non-terminological phraseologisms, on the other, is the same as between term and non-term ${ }^{41}$. Each term has its conceptual field, so it is independent of context and is professionally oriented.

Unlike V. Fleischer, another German researcher, H. Burger, assumes that terms should be included in phraseology. He substantiates his argument by the fact that many professional statements are present in everyday usage. Burger considers as phraseological units not only those terminological phrases that in everyday language reveal "secondary metaphorization, in addition to it, as terminological phrases that are part of everyday use $\mathrm{e}^{42}$. In this case, we are talking about the so-called "semiprofessiona"" texts, in which professional knowledge is passed on to non-specialists. In relation to Christian theological texts, they include the Catechism of the Catholic Church, which, in fact, was written for laymen, non-specialists, as well as a number of works that serve to teach them, including the "Grundkurs Christentum" (the elementary course of Christianity) by Fr. Peter Karl Wallner, monk of the Order of the Cistercians, rector of the Pontifical High School of Heiligenkreuz in Austria. For instance, set expressions from the edition Die Eucharistie: in die Kirche gehen (to go to (the) church; both literally and figuratively) ${ }^{43}$, Gott bei uns, Gott mit uns (hebr. "Immanuel") (God (El)

\footnotetext{
${ }^{39}$ Молотков А. И. Основы фразеологии русского языка / А. И. Молотков. - Л. : Наука, 1977. - С. 61.

${ }^{40}$ Талия В. Н. Исследования по фразеологии / В. Н. Талия // Теоретические проблемы советского языкознания. - М. : Наука, 1968. - С. 272.

${ }^{41}$ Fleischer W. Phraseologie der deutschen Gegenwartssprache / W. Fleischer. Tübingen: Max Niemeyer Verlag, 1997. - S. 72.

${ }_{42}$ Burger. H. Phraseologie. Eine Einführung am Beispiele des Deutschen / H. Burger. Berlin : Erich Schmidt Verlag, 2003. - S. 51.

${ }^{43}$ Wallner K. Die Eucharistie / Pater K. Wallner. - Leipzig : St. Benno-Verlag, 2010. S. 7.
} 
with us) $)^{44}$, der Kuss der Liebe (holy kiss, the kiss of peace) ${ }^{45}$. Phraseological units of this type are either non-idiomatic or insignificantly idiomatic; they are rather semi-idioms/semi-fixed expressions.

M. Dume puts forward several criteria for phraseology in languages for special purposes; in particular, he argues that under certain conditions, the terms of a particular language for special purposes can be regarded as phraseological units. In the language for specific purposes the criteria that define or classify phraseological units (among others, idiomaticity, persistence, conventional usage, lexicalization, reproduction), are essential determinants for phraseological terms, which are now used not for the common language, but the language for special purposes. Phraseological terms are the link between phraseological units and terms. Phraseological terms, according to the definition of phraseology, should always form a group of words, while terms can exist independently as separate words. Phraseological terms can be both idiomatic and non-idiomatic. V. Fleischer's theory changes partially because of the above-mentioned criteria. He rejects the inclusion of phraseological terms into the group. Provided that the above criteria are accepted in the framework of languages for specific purposes studies, we can assume when terms may be defined as phraseological unit in turn, leading us to a transparent extension of the meaning of the phraseology in the study of languages for special purposes $^{46}$.

Furthermore, the conducted analysis based on E. Agricola's dictionary using I. Chernysheva's classification ${ }^{47}$, made it possible to identify the following features in the Christian theological terminology of the German language:

- 28 phraseological unities were recorded:

${ }^{44}$ Wallner K. Wer glaubt wird selig / Pater K. Wallner. - Regensburg : Lübbe, 2009. S. 9.

${ }^{45}$ Wallner K. Die sieben Sakramente / Pater K. Wallner. - Leipzig : St. Benno-Verlag, 2010. - S. 17.

46 Duhme M. Phraseologie der deutschen Wirtschaftssprache: eine empirische Untersuchung zur Verwendung von Phraseologismen in journalistischen Fachtexten / M. Duhme. - Essen : Die Blaue Eule, 1991. - S. 64.

47 Чернышева И. И. Фразеология современного немецкого языка / И. И. Чернышева. - М. : Высшая школа, 1970. - С. 39-46. 
seinen Tag von Damaskus erleben (to convert), das Gelobte Land (the Promised Land), vom Saulus zu Paulus werden (change belief, Conversion of Paul the Apostle), Licht der Welt (the Light of the World), bei Sankt Petrus anklopfen (dying), der barmherzige Samariter (Lk 10, 25-37) (the Good Samaritan);

- 67 phraseological expressions: die Geheimnisse des Rosenkranzes (Mysteries of the Rosary), Heilige Stiege (Scala Santa, Holy Stairs), das babylonische Exil der Päpste (The Avignon Papacy/ the papal exile in Avignon), geschlossene Zeit (closed time/ forbidden time), den Himmel auf Erden haben (to live as in Heaven on Earth), des Menschen Wille ist sein Himmelreich (Man's will is his Heaven), Römisches Messbuch (Roman Missal) and

- 158 phraseological combinations:

der bittere Kelch des Leidens (hard fate).

\section{CONCLUSIONS}

Thus, we can conclude that borrowings in the German theological terminology are very common. The fact, that Latin and Greek were considered for the long period as the languages of the Church it had also influence on the theological terminology as such.

Terminological phraseological unit is a linguistic unit consisting of two or more words, with relatively fixed structure, holistic by meaning, and meets the specifications of both term and phraseology; is existent and quite common in the Christian theological terminology of the German language.

\section{SUMMARY}

Overall, during the etymological analysis of 2230 German Christian theological borrowing terms we have revealed that by origin, Latin and Greek terms form the largest group (67.62\% and $26.24 \%$ respectively) of the total number of borrowed terms. Borrowings from the Hebrew language represent $4.13 \%$ of the analyzed terminological units. The reason for such a large number of borrowings from Latin and Greek is due to the early translations of the Bible into these classic languages, which for a long 
time remained the main means of communication. In addition, the theological writings of the church fathers and much of the theologians' were written in Latin, and fewer in Greek. All of these factors have contributed to the borrowing of such a significant number of Christian theological terms.

Regarding the way borrowings become part of a language, the largest group is direct borrowing, $87 \%$ of all the analyzed terminological units. The remaining $13 \%$ are indirect. The analyzed borrowing terms convey specific concepts of theology and are characterized by high accuracy in designation and denomination.

In the studied terminological system phraseologisms are quite widespread. The phraseological terms of the German Christian theological terminology form a special group of expressions, the semantics of which are normalized within the professional language of theology. Phraseoterms form their own conceptual field, they are professionally oriented. We have recorded 28 phraseological unities, 67 phraseological expressions and 158 phraseological combinations.

\section{REFERENCES}

1. Акуленко В.В. Вопросы интернационализации словарного состава языка / В. В. Акуленко. - Харьков: изд-во Харьк. ун-та, 1972. - $244 \mathrm{c}$.

2. Альфиренко Н.Ф. Фразеология в свете современных лингвистических парадигм : Монография / Н. Ф. Альфиренко. - М. : Элипс, 2008. - 271 с.

3. Белецкий А. А. Об интернационализмах / А. А. Белецкий // Науч. зап. Киев. ун-та. 1955. - Т. 14. - Вип. 2. - С. 59-80.

4. Бельчиков Ю. А. Интернациональная терминология в русском языке / Ю. А. Бельчиков. - М. : Учпедгиз, 1959. - 78 с.

5. Бельчиков Ю. А. Интернациональная терминология в русском языке / Ю. А. Бельчиков. - М. : Учпедгиз, 1959. - 78 с.

6. Володина М. Н. Национальное и интернациональное в процессе терминологической номинации / М. Н. Володина. - М. : Изд-во Моск. ун-та. - 1993. - 112 с. 
7. Д'яков А.С. Основи термінотворення: Семантичні та соціолінгвістичні аспекти / Д'яков А. С., Кияк Т. Р., Куделько 3. Б. К. : вид. дім "КМ Academia", 2000 - 218 с.

8. Даниленко В. П. О терминологическом словообразовании / В. П. Даниленко // Вопросы языкознания. - М. , 1973. - № 4. C. 76-85.

9. Даниленко В. П. Русская терминология: Опыт лингвистического описания / В. П. Даниленко. - М. : Наука, - 1977. - 246 с.

10. Жербило Т. В. Термины и понятия лингвистики : Общее языкознание. Социолингвистика : Словарь-справочник / Т. В. Жербило. - Назрань : Пилигрим, 2011. - 280 с.

11. Кияк Т. Р. Запозичення та інтернаџіоналізми у фахових мовах : [Електронний ресурс] / Т. Р. Кияк // Вісник Житомирського державного університету імені Івана Франка. - 2006. - № 27. - С. 32-34. Режим доступу : http://eprints.zu.edu.ua/1068/1/06ktpifm.pdf.

12. Кокойло О.В. Інтернаціональна лексика в російській та іспанській мовах / О.В.Кокойло, Н.М.Корбозерова // Мовознавство. - 1987. - № 2. - С. 27-32.

13. Крысин Л. П. Языковое заимствование как проблема диахронической социолингвистики / Л. П. Крысин // Диахроническая социолингвистика. - М., 1993. - С. 131-151.

14. Лотте Д. С. Вопросы заимствования и упорядочения иноязычных терминов и терминоэлементов / Д. С. Лотте. - М. : Наука, 1982. - $152 \mathrm{c}$.

15. Молотков А. И. Основы фразеологии русского языка / А. И. Молотков. - Л. : Наука, 1977. - 284 с.

16. Реформатский А. А. Термин как член лексической системы языка / А. А. Реформатский // Проблемы структурной лингвистики. М., 1968. - С. 103-126.

17. Секунда Т. Принципи складання української технічної термінології / Т. Секунда // Вісник Ін-ту укр. наук. мови. - 1930. Вип. 2. - С. 11-21. 
18. Талия В. Н. Исследования по фразеологии / В. Н. Талия // Теоретические проблемы советского языкознания. - М. : Наука, 1968. - C. 257-277.

19. Українська мова : енциклопедія / [Русанівський В. М, Тараненко О. О., М. П. Зяблюк та ін.]. - [2-ге вид., випр. і доп.]. - К. : Українська енциклопедія ім. М. П. Бажана, 2004. - 824 с.

20. Чернышева И. И. Фразеология современного немецкого языка / И. И. Чернышева. - М. : Высшая школа, 1970. - 200 с.

21. Языкознание. Большой энциклопедический словарь / [под ред. В. Н. Ярцевой]. - [2-е изд.]. - М. : Большая Российская энциклопедия, 1998. -685 c.

22. Arntz R. Einführung in die Terminologiearbeit / R. Arntz, H. Picht, F. Mayer. - [5., verb. Aufl.]. - Hildesheim, Zürich , New York : Olms, 2004. - $331 \mathrm{~s}$.

23. Bally Ch. Traite de stylistique francaise / Ch. Bally. - [2. Aufl.]. 2. Bd. - Heidelberg, 1921. - 332 S.

24. Burger H. Handbuch der Phraseologie / H. Burger, A. Buhofer, A. Sialm. - Berlin, 1982. - 433 s.

25. Burger. H. Phraseologie. Eine Einführung am Beispiele des Deutschen / H. Burger. - Berlin : Erich Schmidt Verlag, 2003. - 130 s.

26. Duhme M. Phraseologie der deutschen Wirtschaftssprache: eine empirische Untersuchung zur Verwendung von Phraseologismen in journalistischen Fachtexten / M. Duhme. - Essen : Die Blaue Eule, 1991. $222 \mathrm{~s}$.

27. Eckert R. Die Phraseologie der russischen Sprache / R. Eckert, K. Günther. - Leipzig, Berlin, 1992. - 267 S.

28. Fleischer W. Phraseologie der deutschen Gegenwartssprache / W. Fleischer. - Tübingen: Max Niemeyer Verlag, 1997. - 310 s.

29. Fluck, H.-R. Fachsprachen: Enführung und Bibliographie / HansRüdiger Fluck. - [5. überarb. und erw. Aufl.]. - Tübingen : Basel : Francke, 1996. - 359 s.

30. Haspelmath M. Loanwords in the Word's Languages : A Comparative Handbook / M. Haspelmath, U. Tadmor. - Walter de Gruyter, 2009. - $1081 \mathrm{p}$. 
31. Hauck F. Theologisches Fach- und Fremdwörterbuch / F. Hauck, G. Schwinge - [10., Aufl.]. - Göttingen : Vandenhoeck \& Ruprecht, 2005. - $240 \mathrm{~S}$.

32. Kühn P. Pragmatische und lexikographische Beschreibung phraseologischer Einheiten: Phraseologismen und Routineformeln // Studien zur neuhochdeutschen Lexikographie IV. - [hrgb. Wiegand, H.E.]. Hildesheim, Zürich, New York, 1984. - S. 175-235.

33. Lindquist A. Studien über Wortbildung und Wortwahl im Althochdeutschen mit besonderer Rüchsicht auf die nomina actionis / A. Lindquist // Beiträge zur Geschichte und Sprache der deutschen Literatur. - 1936. - S. 1-132.

34. Palm Ch. Phraseologie. Eine Einführung / Ch. Palm. - Tübingen, 1995. $-224 \mathrm{~s}$.

35. Pilz K. D. Phraseologie: Redensartenforschung / K. D. Pilz. Stuttgart, 1981. - 147 s.

36. Stedje A. Deutsche Sprache gestern und heute / A. Stedje. München, 1989. - 281 s.

37. Wallner K. Die Eucharistie / Pater K. Wallner. - Leipzig : St. Benno-Verlag, 2010. - 95 s.

38. Wallner K. Die sieben Sakramente / Pater K. Wallner. - Leipzig : St. Benno-Verlag, 2010. - 95 s.

39. Wallner K. Wer glaubt wird selig / Pater K. Wallner. Regensburg : Lübbe, 2009. - 350 s.

\section{Information about the author: Veresh M. T.,}

$\mathrm{PhD}$ in Germanic Languages, Associate Professor at the Faculty of Foreign Philology, Department of German Philology

Uzhhorod National University 3, Narodna Sq., 88000, Uzhhorod, Ukraine 